\title{
AN EMPRICIAL STUDY ON THE IMPACT OF FINANCING STRUCTURE ON CORPORATE PERFORMANCE-A CASE STUDY OF LISTED COMPANIES IN CHINA'S FINANCIAL INDUSTRY
}

\author{
Yanping Zhao \\ Shanghai University, P.R.China
}

\begin{abstract}
Financial industry being in a pillar position in China's national economy, reasonable and effective financing structure can enhance the level of corporate performance and promote the stability and efficient development of the financial industry. Based on the data of companies in China 's financial industry during 2007-2016, this paper uses the multiple regression model of panel data to study the impact of debt financing, equity financing and internal financing on corporate performance from the perspective of internal and external financing structure. The results show that the performance of financial listed companies in China is positively related to the financing of debt, which is negatively related to equity financing and endogenous financing. Long-term debt financing has positive effect on performance. The current liabilities ratio is negatively correlated with ROE and EPS. Stock ratio is negatively related to firm performance.
\end{abstract}

Keywords: Financial industry; financing structure; corporate performance; multiple regression model

JEL code: M0, M1

\section{Introduction}

In recent years, the international financial industry is in a strong turbulence. Especially after the 2008 subprime mortgage crisis, the financial institutions are in the reform. Relatively speaking, China's financial industry reform late and the system is not perfect, meeting challenge. At present, most of China's financial institutions are engaged in direct or indirect investment and financing business. Taking banks for example, on the one hand banks need to absorb deposits, that is, to increase the debt to obtain funds, on the other hand through loans to carry out business. So its own financial structure and financing structure will have a certain impact on business performance. More importantly, to a certain extent the financial industry listed companies financing structure will indirectly affect the financial market stability. The general corporate financing structure is divided into external financing and internal financing, and external financing is composed of equity financing and debt financing. Based on the background of the financial industry, this paper studies the relationship between equity financing, debt financing and internal financing and performance of listed companies, and to a certain extent, the extension and expansion of corporate governance theory in China.

\section{Domestic and Foreign Literature Review}

Kraus, Litzenberger (1973) proposed a static trade-off theory that profit and debt were positively correlated, and firms were given the benefits of tax shields; Myers (1984) proposed a new qualifying theory on the basis of MM theory, predicting profits and liabilities. The ratio of direct negative correlation. Xu and Wang (1997) explored the ownership structure of listed 
companies in China, and the result shows that the ownership structure and performance of listed companies are significantly proportional. Booth et al. (2001), based on sample data from 10 developing countries, found a significant negative correlation between debt capital structure and operating performance in other developing countries except for Zimbabwe, influenced by GDP growth factors; J Chen And R Strange (2005) study China 2003 The analysis of the financing structure of 972 listed companies shows that the better the profitability of the company, the lower the debt ratio.

Most studies on the relationship between corporate financing structure and corporate performance in China focus on real estate, new energy, power industry, and emerging industries while few on the financial industry. Lunjian Feng (2014) studied 40 A-share real estate industry listed companies financial data empirical study and found that there is a positive correlation between the financing rate and the performance of the company, but it is negatively correlated with the company's equity financing rate. Yu Xuebin and Zhao Xiaoli (2014) taking the data of 43 listed companies in China as a sample, from the perspective of internal and external corporate governance, the performance of financial companies is negatively correlated with the shareholding ratio of the largest shareholder. There was no significant relationship between the shareholding ratio of the independent directors, the size of the board of directors and the proportion of institutional investors. Zhang (2016) found that corporate performance and asset-liability ratios were not relevant in 1990-2012, but long-term commercial credit had a positive effect on the performance of new energy companies, while firms that relied on short-term loans were more affected by interest rate fluctuations. Wei Lizhi and Guo Shujuan (2016) used factor analysis to study the impact of financing structure on the performance of listed companies. The study shows that equity financing and bond financing can improve the performance of listed companies, while bank loans have a negative impact. Liu Dongshu (2017) used the panel data regression model to find that the performance of new energy enterprises is directly proportional to the scale of assets and liabilities financing, depreciation financing and equity concentration.

Based on the existing researches, this paper analyses the influence of debt financing, equity financing and internal financing on performance, and adds the different financing methods, and control variables such as the concentration of ownership, the nature of the company and more detailed consideration of China's financial industry

\section{Empirical Research}

\subsection{Data Selection}

This paper selects the Chinese A-share listed financial companies, excluding ST companies, data defects in the company after a total of 45 companies, including 16 banks, 18 brokerage firms, 3 insurance companies and other three financial companies. The interception period is from January 1, 2007 to December 31, 2016. The data used in the text are from the wind and Guotai'an database, and use Eviews8.0 on the data processing and the establishment of the model.

\subsection{Variable Selection}

This paper is explained by the variable return on net assets (ROE) and earnings per share (EPS). ROE is a comprehensive and strong indicator, is the international common measure of the basic rate of return indicators, EPS as a general indicator of the growth of the company for 
the performance of the company's performance test.

The explanatory variables are the indicators of debt financing, equity financing and internal financing. Considering that characteristics of the firm itself will affect the company's performance, it adds asset size, growth and corporate nature as a control variable. Asset liability ratio (DBET), long-term debt ratio (LDET) and current gearing ratio (FDET) are the explanatory variables of debt financing .Equity financing rate (EF), large shareholder ratio (TOP), institutions (IN) explain equity financing , where equity financing rate $=$ (share capital + capital reserve) / total assets; Explanatory variables for internal financing are retained earnings (REP) and depreciation financing (DEP), which retained earnings financing = retained earnings / (SIZE), Main Business Growth Rate (PMC) and Enterprise Nature (PD), of which asset size $=\mathrm{LN}$ (total assets), the nature of the enterprise is a dummy variable (total assets), depreciation financing $=$ depreciation $/$ total assets , If the enterprise is a private enterprise, then $\mathrm{PD}=1$, if the state-owned enterprises $\mathrm{PD}=0$.

\subsection{Model Construction and Analysis}

\subsubsection{Descriptive statistics}

In this paper, the 45 listed companies nearly three years of the financial indicators of the descriptive statistical results as follows:

Table 1 Descriptive statistical results

\begin{tabular}{l|l|l|l|l|l|l|l|l|l|l|l|l|l}
\hline \multicolumn{1}{c|}{ V } & N & \multicolumn{5}{c|}{2016} & \multicolumn{4}{c|}{2015} & \multicolumn{4}{c}{2014} \\
\hline & & Mean & \multicolumn{1}{c|}{ Max } & \multicolumn{1}{c|}{ Min } & SD & Mean & Max & Min & SD & Mean & Max & Min & SD \\
\hline ROE & 45 & 16.138 & 264.214 & -37.901 & 40.300 & 16.396 & 42.514 & -23.029 & 11.120 & 14.757 & 40.966 & -8.303 & 8.490 \\
\hline EPS & 45 & 0.407 & 2.280 & -0.429 & 0.561 & 0.652 & 2.660 & -0.071 & 0.576 & 0.690 & 3.280 & -0.086 & 0.661 \\
\hline DEBT & 45 & 73.846 & 113.714 & 17.665 & 24.082 & 71.937 & 96.815 & 19.412 & 22.930 & 72.389 & 96.518 & 24.146 & 23.391 \\
\hline LDET & 45 & 12.087 & 86.788 & 0.000 & 21.436 & 12.015 & 67.517 & 0.000 & 20.511 & 9.672 & 66.071 & 0.000 & 17.766 \\
\hline FDET & 45 & -1.561 & 5.840 & -22.763 & 5.376 & -2.337 & 1.484 & -32.859 & 7.204 & -2.057 & 1.334 & -33.507 & 6.686 \\
\hline EF & 45 & 28.731 & 129.692 & 1.332 & 33.396 & 30.839 & 142.111 & 1.262 & 37.252 & 26.857 & 128.932 & 1.669 & 32.109 \\
\hline TOP & 45 & 32.055 & 100.000 & 5.900 & 20.301 & 31.499 & 100.000 & 5.900 & 19.837 & 31.675 & 100.000 & 6.750 & 19.482 \\
\hline IN & 45 & 28.591 & 78.462 & 0.491 & 21.610 & 36.905 & 97.112 & 0.457 & 24.202 & 48.971 & 97.058 & 3.187 & 24.209 \\
\hline REP & 45 & -4.675 & 14.840 & -97.247 & 23.306 & -4.796 & 18.656 & -126.259 & 28.705 & -1.101 & 32.657 & -102.992 & 21.350 \\
\hline DEP & 45 & 5.957 & 57.491 & 0.000 & 13.230 & 6.162 & 51.840 & 0.000 & 12.397 & 5.462 & 47.796 & 0.043 & 11.767 \\
\hline SIZE & 45 & 24.479 & 29.793 & 19.491 & 3.163 & 24.434 & 29.909 & 19.675 & 3.277 & 24.819 & 30.098 & 19.664 & 3.250 \\
\hline PMC & 45 & -6.592 & 67.404 & -136.802 & 44.622 & 151.634 & 6248.037 & -315.781 & 931.451 & 465.781 & 20239.110 & -45.519 & 3014.725 \\
\hline PD & 45 & 0.644 & 1.000 & 0.000 & 0.484 & 0.644 & 1.000 & 0.000 & 0.484 & 0.644 & 1.000 & 0.000 & 0.484 \\
\hline
\end{tabular}

From the table can be seen, the financial industry 45 companies nearly three years of ROE mean are about $16 \%$, indicating that the financial industry listed companies have a high rate of return; Asset-liability ratio of the annual average about $72 \%$ indicats that the proportion of liabilities in the company's assets is higher than the equity, the maximum value from $96.52 \%$ in 2014 to $113.71 \%$ in 2016, indicating that the company's asset-liability ratio is to be strengthened. In the debt structure of listed companies in the financial industry, the short-term liabilities of listed banks, securities companies and insurance companies are relatively small, while other types of financial companies have short-term liabilities of about $80 \%$. Long-term debt ratio mean value of short-term debt ratio also indicates that corporate bond financing preferred long-term liabilities. In the shareholding structure, the equity financing rate in the past three years is about $28 \%$, which indicates that the proportion of the listed companies in the financial industry is at the middle level. The average shareholding ratio of the largest 
shareholder is about $32 \%$, which indicates that the concentration of equity is higher, the control of large shareholders is stronger; The average value of institutional investors is about $28.59 \%$, and the proportion of institutions is not high. In terms of control variables, the variance of the size of the assets of the financial industry is small and there is not much difference in overall. In general, the financial sector of the city's financing structure as a whole is the equity financing than debt financing accounted for a relatively high proportion.

\subsubsection{Panel Regression Analysis}

ROE, EPS two indicators respectively are used to measure Y. The model uses panel data regression, the model is constructed as follows:

A. The impact of debt financing on corporate performance

Model 1 is as follows: $Y_{\mathrm{it}}=\beta_{0}+\beta_{1} D E T_{i, t}+\beta_{2} Z+\varepsilon_{i, t}$

Model 2 is as follows: $Y_{\mathrm{it}}=\beta_{0}+\beta_{1} \operatorname{LDET}_{i, t}+\beta_{2} \operatorname{SDET}_{i, t}+\beta_{3} Z+\varepsilon_{i, t}$

Table 2 Financial industry listed companies creditor rights structure and performance relationship

Note: * and ${ }^{* *}$ represent significant at $10 \%$ and 5\%, respectively. FDET barely significant at $10 \%$ level, FDET P

\begin{tabular}{|c|c|c|c|c|c|c|c|c|c|c|c|}
\hline & \multicolumn{5}{|c|}{ MODEL 1} & \multicolumn{6}{|c|}{ MODEL 2} \\
\hline $\mathrm{V}$ & C & DEBT & SIZE & PMC & PD & C & LDET & FDBT & SIZE & PMC & PD \\
\hline ROE & $\begin{array}{l}26.1285^{*} \\
(8.2574)\end{array}$ & $\begin{array}{l}0.3612^{* *} \\
(0.0567)\end{array}$ & $\begin{array}{l}-1.4555^{* *} \\
(0.4369)\end{array}$ & $\begin{array}{l}0.0001 \\
(0.0003)\end{array}$ & $\begin{array}{l}-1.9884 \\
(1.6415)\end{array}$ & $\begin{array}{l}-29.8421 \\
(8.5613)\end{array}$ & $\begin{array}{l}0.1918^{* *} \\
(0.0575)\end{array}$ & $\begin{array}{l}-0.2329 \\
(0.1468)\end{array}$ & $\begin{array}{l}1.6766^{* *} \\
(0.3196)\end{array}$ & $\begin{array}{l}0.0000 \\
(0.0004)\end{array}$ & $\begin{array}{l}-1.1559 \\
(1.6854)\end{array}$ \\
\hline EPS & $\begin{array}{l}-2.2895^{*} \\
(0.3261)\end{array}$ & $\begin{array}{l}0.0058^{* *} \\
(0.0022)\end{array}$ & $\begin{array}{l}0.0959^{* *} \\
(0.0173)\end{array}$ & $\begin{array}{l}0.0000 \\
(0.0000)\end{array}$ & $\begin{array}{l}0.3203^{* *} \\
(0.0648)\end{array}$ & $\begin{array}{l}-2.6994 \\
(0.3314)\end{array}$ & $\begin{array}{l}-0.0119 \\
(0.0020)\end{array}$ & $\begin{array}{l}-0.0065 \\
(0.0061)\end{array}$ & $\begin{array}{l}0.0289^{* *} \\
(0.0022)\end{array}$ & $\begin{array}{l}0.0000 \\
(0.0000)\end{array}$ & $\begin{array}{l}0.2473^{* *} \\
(0.0693)\end{array}$ \\
\hline
\end{tabular}

value is 0.1135 .

The asset-liability ratio of the listed companies in the financial industry is positively correlated with the EPS at the statistical level of 5\%, indicating that the positive impact of debt financing on the company exceeds the negative impact. On the one hand, the tax-saving effect of debt plays a role, and the other is the incentive effect of the debt to the managers, so that managers as much as possible into the high level of profitability of high-quality projects to promote the company's performance improvement The regression results are basically consistent with the static trade-off theory. But in recent years, the financial industry listed companies have high asset-liability ratio, there is a certain financial risk, so the need to properly control the company's debt size. Long-term debt financing is more likely to determine the future cash flow than the current debt financing, and it is easier for the financial industry to carry out the investment and financing. In the case of the long-term debt financing, it is easier for the long-term debt financing to have a positive effect on the ROE. Loans and other main business, increase the company's main business income, improve corporate performance.

B.The Impact of Equity Financing on Corporate Performance

Model 3 is as follows: $Y_{\mathrm{it}}=\beta_{0}+\beta_{1} E F_{i, t}+\beta_{2} Z+\varepsilon_{i, t}$

Model 4 is as follows: $Y_{\mathrm{i} t}=\beta_{0}+\beta_{1}$ TOP ${ }_{i, t}+\beta_{2} I N_{i, t}+\beta_{3} Z+\varepsilon_{i, t}$ 
Table 3 Financial industry listed companies equity structure and performance relationship

\begin{tabular}{|c|c|c|l|l|l|l|l|l|l|l|l|c|}
\hline & \multicolumn{9}{|c|}{ MODEL 3 } & \multicolumn{6}{c|}{ MODEL 4 } \\
\hline V & C & EF & SIZE & PMC & PD & C & TOP & IN & SIZE & PMC & PD \\
\hline ROE & 2.41002 & -0.0461 & 0.5150 & 0.0002 & -0.7189 & -9.3185 & -0.0416 & $-0.0879^{* *}$ & $1.1872^{* *}$ & 0.0002 & -1.8684 \\
& $(10.352)$ & $(0.0370)$ & $(0.3767)$ & $(0.0004)$ & $(1.7084)$ & $(6.7986)$ & $(0.0532)$ & $(0.0382)$ & $(0.2867)$ & $(0.0004)$ & $(1.8726)$ \\
\hline EPS & $-2.1332^{* *}$ & $-0.0032^{* *}$ & $0.1086^{* *}$ & 0.0000 & $0.3437^{* *}$ & $-2.6130^{*}$ & $-0.0128^{* *}$ & -0.0011 & $0.1468^{* *}$ & 0.0000 & $0.1550^{* *}$ \\
& $(0.3909)$ & $(0.0022)$ & $(0.0142)$ & $(0.0000)$ & $(0.0645)$ & $(0.2464)$ & $(0.0019)$ & $(0.0014)$ & $(0.0104)$ & $(0.0000)$ & $(0.0679)$ \\
\hline
\end{tabular}

Note: $*$ and $* *$ represent significant at $10 \%$ and $5 \%$, respectively.

Under the 5\% statistical level, the equity financing rate is negatively correlated with EPS and is also negatively correlated with ROE, which reflects that the value of equity financing of listed companies in the domestic financial industry has not been fully used to improve the performance of the company. Most of China's enterprises prefer equity financing, Equity financing in the short term has the characteristics of stability and low financial risk, but the long term to see the low price of equity financing will have a proxy problem, especially when the poor business caused by stock prices fall easily lead to changes in control and malicious acquisitions, etc. The empirical results show that the proportion of large shareholders and performance-related negative, the proportion of large companies in the financial industry is too high, on the one hand to do business decisions to be more consistent and more power to supervise the management Behavior, reduce the cost of agency, but on the other hand, the major shareholders have the right to control the company for their own interests and damage the interests of small shareholders, which is not conducive to the improvement of corporate governance efficiency. Institutional investors are a major channel for financial sector finances, and institutional investors have more detailed investment analysis and other investors' ability to influence their share prices for their own interests, thereby affecting corporate performance.

C.The impact of internal financing on performance

Model 5 is as follows: $Y_{\mathrm{it}}=\beta_{0}+\beta_{1} R E P_{i, t}+\beta_{2} D E P_{\mathrm{i}, t}+\beta_{3} Z+\varepsilon_{i, t}$

Table 4 Financial industry listed companies internal financing structure and performance relationship

\begin{tabular}{|c|l|l|l|l|l|l|}
\hline & \multicolumn{6}{|c|}{ MODEL 5 } \\
\hline V & \multicolumn{1}{|c|}{ C } & \multicolumn{1}{|c|}{ REP } & DEP & SIZE & \multicolumn{1}{|c|}{ PMC } & \multicolumn{1}{c|}{ PD } \\
\hline ROE & 6.5119 & $-0.1723^{* *}$ & $-0.4756^{* *}$ & 0.3966 & 0.0003 & -1.0842 \\
& $(7.8007)$ & $(0.0415)$ & $(0.1172)$ & $(0.2925)$ & $(0.0004)$ & $(1.6758)$ \\
\hline EPS & -2.7235 & -0.0009 & -0.0018 & $0.1289^{* *}$ & $0.0000^{* *}$ & $0.3461^{* *}$ \\
& $(0.3039)$ & $(0.0016)$ & $(0.0014)$ & $(0.0114)$ & $(0.0000)$ & $(0.0653)$ \\
\hline
\end{tabular}

Note: $*$ and $* *$ represent significant at $10 \%$ and $5 \%$, respectively.

For the financial industry listed companies, endogenous financing and corporate performance was negatively correlated. EPS is the measure of depreciation financing because the tax credit makes the earnings per share lower, so the correlation coefficient is negative. Indeed, the use of internal financing in terms of external financing, the use of less restrictive, low cost, do not need to pay dividends or interest, no debt service pressure, but for the financial institutions within the financing of the shortcomings of more than the advantages of endogenous financing But the company's performance deteriorated.

On the control variables, the total assets of the listed companies in the financial industry are positively related to the corporate performance, and the business risk and financial risk are reduced when the enterprise develops to a certain scale. The increase in the profit growth rate 
of the Company will help to continue to carry out business with the Company and improve the Company's performance level and reputation so as to further improve the performance level.

\section{Conclusions and Recommendations}

\subsection{The Main Conclusion}

From the above empirical analysis results can be drawn from the following conclusions: liabilities will have a positive impact on corporate performance, enterprises in order to reduce the internal and external information asymmetry and win managers prefer to improve the current debt ratio rather than long-term debt ratio to positively affect business performance.(1)The proportion of equity financing of listed companies in China's financial industry is the largest proportion of financing structure, and the proportion of debt financing and internal financing is low. The financing of debt has a positive correlation with the performance of financial industry listed companies, and there is a negative correlation between equity financing and internal financing (2) From the term of the debt point of view, long-term debt financing has a positive effect on the ROE, the current liabilities, but also because of the financial assets of listed companies in a higher position.It is also necessary o find the optimal level of debt financing; Rate and ROE and EPS negative correlation, so the financial industry listed companies may be appropriate to increase long-term liabilities, reduce current liabilities. (3) Retained earnings and depreciation financing is not conducive to the improvement of corporate performance.

\subsection{Recommendations}

Based on the above conclusions, this paper puts forward relevant policy suggestions from the following aspects.

(1) Optimize the financing structure, to determine the appropriate asset-liability ratio. From the above analysis, we can see that the financing of equity in the financial industry listed companies is related to the performance of the company, and the debt financing is positively related to the performance of the company. Therefore, the proportion of equity financing should be weakened by the financing of the external financing. business performance. From the above analysis can be seen in the financial industry, the company's asset-liability ratio is relatively high, on the one hand is conducive to the improvement of corporate performance, while, on the other hand there are financial risks, easily lead to bankruptcy and mergers and acquisitions, so financial Listed companies need to determine the optimal asset-liability ratio, reduce financing costs and improve corporate performance.

(2) Improve the company's equity structure. In the ownership structure, the appropriate reduction in the proportion of the largest shareholder of the shareholding, reduce the stock too concentrated, so that the appropriate decentralized ownership structure. Because in the financial industry, the proportion of large shareholders holdings, it is easy to ignore the interests of stakeholders and the stability of the financial system. The proportion of shareholders between the balance of the balance and try to avoid the interests of major shareholders, to prevent the company decided to authoritarian, is not conducive to corporate governance efficiency and performance improvement.

(3)To create a diversified financing system. In order to weaken the financial risks, we should 
build a diversified financing system. When financing the financial listed companies, we should fully consider the scale of the company, the growth ability, the business plan, the debt service plan and so on. In order to reduce the financial risk, Factors to develop financing policies to determine the different financing structure.

\section{References}

Appiadjei, E.A. Capital structure and firmperformance: evidence from Ghana stock exchange [J] .Research Journal of Finance and Accounting, 2014, 5 (16): 37- 43.

Anastassios A. Drakos, Georgios P. Kouretas.Bank ownership, financial segments and the measurement of systemic risk: An application of CoVaR [J].International Review of Economics \& Finance, 2015, 40: Pages 127-140.

Chen Ju-liang, Li You-gen.Study on the Impact of Corporate Governance on Corporate Performance - A Case Study of Real Estate Listed Companies [J]. Finance \& Economics, 2017 (07): 35-40

Li Zhiguo, Pan Xinxin. Research on the Financial Support for the Development of New Energy Industry in China - Based on the Data of Listed Companies from 2003 to 2012 [J]. Industrial Technology \& Economy, 2015,264 (10): 151- 160.

Li Jiabin, Jiang Wei. Empirical analysis of the effect of ownership structure on firm performance [J]. Finance \& Accounting, 2011 (3): 100-103.

Masulis, Ronald W. The impact of capital structure change on firm value: some estimates [J] .The Journal of Finance, 1983, 1 (38): 107- 126.

Myers, S.C., Majluf., N.S. Corporate financing and Investment terms the firms have information that investors do not have [J].Journal of Financial Economics, 1984 (13): 187-221.

Zhang et.al. Exuberance in China's renewable energy investment: Rationality, capital structure and implications with firm level evidence [J].Energy Policy, 2016 (95): 468- 478.

Zhao Xin. Research on the relationship between corporate governance and corporate performance [J]. Friends of Accounting, 2010 (6): 83-85. 